\title{
Peran Guru Sejarah dalam Pemanfaatan Inovasi Media Pembelajaran
}

\author{
Agus Susilo $^{1)}$, Andriana Sofiarini ${ }^{2)}$ \\ ${ }^{1}$ Program Studi Pendidikan Sejarah STKIP PGRI Lubuklinggau ${ }^{2}$ Program Studi Pendidikan Guru \\ Sekolah Dasar STKIP PGRI Lubuklinggau \\ 1 agussusilo4590@gmail.com ${ }^{2}$ andriesophie205@gmail.com
}

\begin{abstract}
Abstrak
Tujuan penulisan karya ilmiah ini adalah untuk menambah wawasan dan bahan referensi bagi guru-guru sejarah tentang pentingnya berkreativitas dan berinovasi terhadap pembelajaran sejarah melalui media pembelajaran inovatif. Dalama penelitian ini ini, peneliti menggunakan metode penelitian kualitatif deskriptif. Sumber yang menjadi acuan penelitian ini adalah berdasarkan hasil pengamatan lapangan dan sumber referensi terkait penelitian. Hasil penelitian ini adalah meliputi: 1) Guru Sejarah memiliki daya saing, maksudnya guru sejarah mampu berdiri dengan kemajuan zaman dan mampu menyesuaikan dengan keadaan saat ini, 2) Guru Sejarah memiliki kemampuan terhadap teknologi, artinya gurusejarah mampu mengoperasikan bahkan mendesain materi sejarah dengan bantuan teknologi, 3) Guru Sejarah berpikir kreatif, artinya guru sejarah mampu memecahkan masalah yang muncul dalam pembelajaran sejarah itu sendiri, 4) Guru Sejarah memiliki inovatif dan kreatif dalam memanfaatkan media pembelajaran, artinya, perkembangan zaman membuat guru sejarah memiliki kemampuan yang luas dalam berkreasi terhadap beberapa media, 5) Guru Sejarah berinovasi dengan media pembelajaran, artinya kemampuan guru sejarah dalam berinovasi dengan mendesain berbagai media dengan materi sejarah yang menarik, 6) Tantangan dalam memanfaatkan media teknologi, artinya guru sejarah melihat kemajuan zaman sebagai tantangan yang harus dimanfaatkan untuk tetap memprioritaskan masa depan bangsa Indonesia. Berdasarkan hasil di atas dapat disimpulkan bahwa guru-guru sejarah harus mengikuti perkembangan zaman dalam memodifikasi pembelajaran agar dapat meningkatkan pemahaman dan prestasi siswa di Sekolah.
\end{abstract}

Kata Kunci: Guru Sejarah, Inovasi, Media, Pembelajaran

\section{The Role of History Teachers in Utilizing Learning Media Innovations}

\author{
Agus Susilo $^{1)}$, Andriana Sofiarini ${ }^{2)}$ \\ ${ }^{1}$ History Education Program of STKIP PGRI Lubuklinggau ${ }^{2}$ Primary School Teacher Education Study \\ Program STKIP PGRI Lubuklinggau \\ ${ }^{1}$ agussusilo4590@gmail.com ${ }^{2}$ andriesophie205@gmail.com
}

\begin{abstract}
The purpose of writing this scientific paper is to add insight and reference material for history teachers about the importance of being creative and innovating towards learning history through innovative learning media. In this study, researchers used descriptive qualitative research methods. The source of this research is based on field observations and reference sources related to research. The results of this study include: 1) History teachers have competitiveness, meaning that history teachers are able to stand up to the times and are able to adapt to current conditions, 2) History teachers have the ability to technology, meaning that history teachers are able to operate and even design historical material with the help of technology, 3) History teachers think creatively, meaning that history teachers are able to solve problems that arise in history learning itself, 4) History teachers are innovative and creative in utilizing instructional media, meaning that the times have made history teachers have broad abilities in being creative with several media, 5) History teachers innovate with instructional media, meaning the ability of history teachers to innovate by designing various media with interesting historical material, 6) Challenges in utilizing technological media, meaning that history teachers see the progress of the times as a challenge that must be utilized to prioritize the future of the Indonesian nation. Based on the above results, it can be concluded that history teachers must keep up with the times in modifying learning in order to increase student understanding and achievement in school.
\end{abstract}

Keywords: History Teacher, Innovation, Media, Learning 


\section{PENDAHULUAN}

Pendidikan merupakan usaha sadar alam mencerdaskan kehidupan berbangsa dan bernegara, yang mana melalui dunia pendidikan anak menjadi tumpuan masyarakat untuk membina diri agar menjadi manusia yang cerdas, terampil dan taqwa kepada Tuhan Yang Maha Esa, maka peningkatan pendidikan dimaksudkan untuk meningkatkan kualitas manusia yang mampu memelihara dan mempertahankan identitas bangsa(Sadikin, 2019).

Saat ini Indonesia telah memasuki era revolusi 4.0 yang ditandai dengan perkembangan teknologi yang begitu cepat terutama teknologi komunikasi dan dipermudahnya penggunaan jaringan internet (Agustiningsih, 2019). Menurut Suyatno dalam (Susilo \& Irwansyah, 2019). Saat ini mutu guru di tanah air dipandang sangat rendah kompetensinya dari kompetensi pedagogis maupun kompetensi keilmuannya. Pada masa lalu, yaitu masa penjajahan dan pasca kemerdekaan sampai tahun 1960-an, mutu guru relatif baik.

Guru sejarah yang sebelumnya hanya berinovasi pada kehidupan masa lalu, saat ini harus diubah pemikirannya terhadap situasi dan kondisi saat ini. Iklim pendidikan saat ini, banyak dipengaruhi oleh kemajuan zaman. Pengelolaan kelas perlu menciptakan suasana gembira atau menyenangkan di lingkungan sekolah melalui pengelolaan kelas, dengan menjalin keakraban antara guru dan siswa, maka guru dapat mengarahkan siswa dengan lebih mudah untuk mendorong dan memotivasi semangat belajar siswa (Minsih \& Galih D, 2018). Salah satu pendekatan pembelajaran yang dianggap bagus dan layak untuk diterapkan dalam proses pembelajaran adalah PAIKEM, singkatan dari Pembelajaran Aktif, Inovatif, Kreatif, Efektif dan Menyenangkan. Di era kontemporer ini, PAIKEM sangat dianjurkan mengingat semakin kompleksnya permasalahan di dunia pendidikan dan juga besarnyatuntutan yang dibebankan kepada guru dalam menyukseskan pembelajaran di Sekolah ataupun para dosen di Universitas (Setiono, Panut \& Rami, 2017).

Hasil observasi yang dilakukan peneliti oleh pada tanggal $11-13$ Februari 2020, terhadap kelas 10.a IPS SMA Negeri 5 Lubuklinggau pada saat mata pelajaran sejarah, diketahui bahwa guru sejarah dalam mangajar masih menggunakan metode konvensional. Diketahui bahwa guru sejarah belum memanfaatkan media pembelajaran yang inovatif. Buku ajar dan lembar kerja siswa (LKS), masih dominan digunakan oleh guru sejarah dalam mengajar dikelas. Maka hal tersebut yang menjadi acuan peneliti untuk mengenalkan media inovatif yang sesuai dengan perkembangan zaman, seperti media audio visual, rumah belajar online, dan lain 
berbagai multimedia lainnya yang dapat dimanfaatkan oleh guru sejarah.

Berpikir Disruptif dan teknologi Revolusi Industri 4.0 membawa perubahan dalam kehidupan di masyarakat. Perkembangan sejarah kehidupan manusia telah menyajikan kebenaran empirik teruji dalam waktu yang sangat panjang. Dalam kehidupan Abad ke-21 penuh dengan perubahan dari kehidupan sebelumnya dalam dimensi yang lebih luas dan skala yang lebih tinggi karena inovasi dalam berpikir dan teknologi yang juga lebih beragam dan berderajat tinggi (Hasan, 2019).

Pencapaian tujuan pembelajaran tidak lepas dari peran pendidik dalam mendidik peserta didik agar menjadi manusia yang selalu mengikuti perkembangan zaman tanpa meninggalkan akar budaya. Pendidikan yang di sisipkan budaya dan karakter dapat membentuk nilai dan karakter sebagai anggota masyarakat, dan warga negara yang religious, nasionalis, produktif dan kreatif (Mansur, 2020).

Guru didorong untuk melakukan berbagai inovasi pembelajaran agar pembelajaran dapat berjalan secara efektivitas, efisiensi dan produktivitas sehingga mutu pembelajaran dapat meningkat. Pembelajaran dapat berjalan dengan lebih baik apabila ditunjang dengan kreatifitas guru dalam meningkatkan mutu pembelajaran (Supriadi, 2017).

Inovasi pembelajaran yang dilakukan disini adalah dengan memberikan suatu inovasi pembelajaran kelompok, dimana siswa akan membentuk kelompokkelompok kecil. Setelah itu kelompokkelompok tersebut diberi materi yang kemudian dijadikan sebagai bahan diskusi kelompok-kelompok tersebut, setelah mereka melakukan diskusi mereka harus mempresentasikan hasil diskusinya. Dalam sesi presentasi siswa lain yang berasal dari luar kelompok tersebut diperbolehkan untuk menanggapi apa yang dipresentasikan oleh kelompok tersebut, entah itu dalam bentuk pertanyaan atau tambahan (Pramayogi, 2019).

Guru sejarah saat ini dengan segala keahlian dan kreativitasnya dapat membawa media yang akan diajarkan didalam pembelajaran. Sejarah masa silam yang seakan-akan hanya sebuah cerita saja, dapat diolah menjadi narasi nyata dengan bantuan media pembelajaran. Tentunya keahlian guru sejarah sendiri harus dibarengi dengan kemampuan berinovasi terhadap media. Pembelajaran sejarah harus menyenangkan dan menarik dengan menghadirkan media di dalamnya.

\section{METODE}

Dalam penulisan karya ilmiah ini, penulis menggunakan metode deskriptif kualitatif. Penulisan ini juga didasarkan 
pada hasil pengamatan didunia pendidikan yang sering kali menjadi problem bagi guru-guru sejarah dalam mengajar. melalui pengamatan di lapangan dan mendeskripsikan melalui tulisan diharapkan mampu menjadi pemahaman bagi guruguru sejarah di era globalisasi saat ini. sumber-sumber penulisan karya ilmiah ini selain didasarkan pada aspek pengamatan juga melalui berbagai sumber referensi, seperti jurnal yang relevan.

Teknik pengumpulan data ini dengan menggunakan observasi. Menurut (Sugiyono, 2018), observasi adalah teknik penelitian dengan melihat perilaku manusia, proses kerja, dan gejala-gejala alam yang diamati dalam lingkup kecil. Melalui studi lapangan (observasi) yang dilakukan peneliti pada tanggal 11 -13 Februari 2020, peneliti melakukan observasi di kelas 10.a IPS SMA Negeri 5 Lubuklinggau pada saat mata pelajaran sejarah. Selama kurang lebih satu minggu, diketahui bahwa guru-guru sejarah masih belum banyak yang memanfaatkan media pembelajaran. Proses pengajaran masih banyak yang menggunakan buku cetak dan lembar kerja siswa (LKS). Observasi atau pengamatan adalah aktivitas penelitian yang menggunakan indera mata. Observasi yang dikaji ini melalui penglihatan, penciuman, pendengaran, peraba, dan pengecap. Selain menggunakanm observasi, penelitian ini juga menggunakan sumber referensi buku dan jurnal yang relevan dengan penelitian (Arikunto, 2013).

\section{PEMBAHASAN}

\section{Guru Sejarah Memiliki Daya Saing}

Pendidikan terutama pembelajaran di lembaga formal memiliki tugas dan tanggung jawab yang berat yaitu mempersiapkan Sumber Daya Manusia yang mampu menghadapi tantangan perubahan zaman yang tengah berlangsung dan yang akan terus berkembang maju. Pendidikan yang tengah berlangsung harus mampu mempersiapkan siswa minimal lima kompetensi yang dibutuhkan di era globalisasi ini, yaitu: (1) kompetensi intelektual, (2) kompetensi personal, (3) kompetensi komunikatif, (4) kompetensi sosial budaya, dan (5) kompetensi kinestesis vokasional.

Kompetensi intelektual harus diikuti pula dengan kompetensi personal, antara lain berupa kemandirian, kekritisan, keuletan, independensi, kejujuran, keberanian, keadilan, keterbukaan, kemampuan mengelola diri sendiri dan kemampuan menempatkan diri. Diharapkan, dengan kedua kompetensi ini akan dihasilkan manusia yang memiliki keluhuran jiwa dan moral yang baik untuk membawa bangsa dan negara ke arah kemajuan dan bangsa yang bermoral dan beragama (Istiarsono, 2016). 
Perkembangan ilmu pengetahuan dan teknologi yang demikian pesat saat ini memberikan dampak positif bagi dunia pendidikan. Sejalan dengan hal itu pemerintah berusaha untuk meningkatkan mutu Pendidikan dengan mengadakan peningkatan kompetensi guru dan perbaikan kurikulum sesuai dengan kemajuan zaman, meningkatkan kualitas para pendidik dan menyediakan mediamedia pendidikan mulai dari yang sederhana sampai yang paling kompleks. Hal ini di maksudkan agar output pendidikan menjadikan manusia yang berkompeten yaitu manusia yang memiliki daya saing ilmu pengetahuan dan teknologi.

Teknologi dapat membantu mencapai sasaran dan tujuan Pendidikan, sehingga proses belajar mengajar akan lebih berkesan dan bermakna. Perkembangan teknologi yang canggih dapat membuat kreativitas setiap orang, utamanya guru diupayakan meningkat. Oleh karena itu, seorang guru harus berinovasi dalam membuat atau menciptakan berbagai macam media pembelajaran (Risma, Juraid, 2016).

Media pembelajaran yang didesain oleh guru sejarah pada dasarnya adalah untuk memberikan rangsangan pada siswa dalam mempelajari sejarah. Menjadi tantangan tersendiri jika media pembelajaran tidak dikembangkan atau bahkan tidak ada.
Beberapa hal jika guru sejarah tidak memanfaatkan media pembelajaran, yaitu: media pembelajaran pertama, mengalami kesulitan dalam mengajar, materi menjadi monoton dan peserta didik merasa bosan dengan apa yang diajar oleh pendidik. Kedua, peserta didik sulit mengerti dan memahami materi pembelajaran. Ketiga, peserta didik susah menangkap penjelasan dari dosen/guru. Keempat, peserta didik merasan bosan dengan materi tersebut. Kelima, peserta didik susah berpikir (Tafonao, 2018).

\section{Guru Sejarah Memiliki Kemampuan Terhadap Teknologi}

Teknologi informasi memiliki peran terciptanya, interaksi antara dosen dan peserta didik (mahasiswa) bukanlah sebuah halangan yang berarti lagi. Saat ini teknologi melalui media telah menjadi solusi pembelajaran yang dapat dilakukan dimana pun dan kapan pun. Teknologi media memberikan ruang bagi dosen untuk memberikan informasi dalam bentuk file (dokumen, Audio, video), melalukan interaksi melalui chat, dan melalakukan evaluasi melalui media (Asmi, 2019).

Perkembangan yang cepat dari teknologi akan mengakibatkan terjadinya tumpukan pengetahuan yang akan dipelajari oleh peserta didik. Jika hanya mengharapkan transfer 
pengetahuan dari guru, jelas peserta didik tidak akan mampu mengikuti perkembangan IPTEK dan akan mengalami ketertinggalan (Ratumanan, 2015).

Dampak instruksional merupakan implikasi proses pembelajaran sejarah yang diharapkan meningkatkan: (1) penguasaan kompetensi sejarah, (2) pengembangan sikap meliputi penghargaan dan bertindakan secara positif, dan (3) pengembangan keterampilan sosial peserta didik yang terwujud dari tindakan yang dilakukan selama proses pembelajaran berlangsung. Melalui ketiga komponen itu diharapkan dapat memetik keteladanan dari topik/tema sejarah yang disajikan. Dampak pengiring timbul apabila proses pembelajaran sejarah memberi kontribusi terhadap penguatan nilai yang berdampak terhadap lingkungan sosial peserta didik. Sistem pendukung adalah perangkat dan alat bantu yang digunakdn guru sejarah dalam proses pembelajaran. Yang dimaksud dengan sistem pendukung adalah RPP, lembar evaluasi, lembar latihan lanjutan, dan alat bantu pembelajaran lainnya (Joebagio, 2017).

Sejalan dengan hal itu, Kemendikbud (2018) dalam (Kristanti \& Umamah, 2019), merumuskan bahwa paradigma pembelajaran abad 21 menekankan pada kompetensi sikap spiritual, sikap sosial, pengetahuan dan keterampilan. Dengan didukung konsep berpikir abad 21 di Indonesia yang bersifat multidisiplin artinya semua materi disadarkan pada Penguatan Pendidikan Karakter pada Pengembangan Karakter (Character Building) dan Nilai Spiritual (Spiritual Value)

Pendidikan di abad 21 tidak hanya menekankan pada aspek kognitif tetapi juga dibutuhkan teori yang dapat mendemonstrasikan pemahaman peserta didik dalam berpikir tingkat tinggi, pengembangan struktur metakognitif, pengembangan sikap, kecerdasan emosional serta pendidikan karakter. Salah satu mata pelajaran yang mampu mengimplementasikan karakter dalam proses pembelajaran adalah materi sejarah.

\section{Guru Sejarah Berpikir Kreatif}

Kemampuan berpikir kreatifimajinatif peserta didik akan terbentuk apabila proses pembelajaran member ruang untuk itu. Sebaliknya kemampuan tersebut tidak akan terbentuk apabila pembelajaran sejarah lebih banyak berisi pemaparan fakta-fakta, fokus pada masa lalu dan berakhir pada kurun waktu zaman tertentu dan tidak dihubungkan dengan persoalan kekinian. Di era teknologi informasi dan komunikasi dimana sumber pembelajaran sejarah sangat berlimpah guru dan peserta didik memiliki peluang untuk mengajar dan belajar sejarah dengan kreatif. Guru bisa menggunakan metode tradisional melalui cerita sambil mengajak peserta didik berimajinasi ke zaman yang dipelajarinya. 
Guru dapat memfasilitasi peserta didik "berwisata" ke masa lalu untuk bermetafora dan melalukan tindakan-tindakan historis. Dari hasil "wisata" itu, mereka bisa ditugasi untuk memerankan dirinya sebagai pelaku sejarah pada zamannya.

Pemanfaatan teknologi komunikasi dan informasi yang tersedia di era ini akan sangat membantu. Pemutaran film sebagai media pembelajaran atau pemanfaatan alat perekam yang tersedia dalam gawai peserta didik bisa menghasilkan gagasan kreatifimajinatif sekaligus produk atau hasil dari pembelajaran. Guru sejarah bukan sebagai pihak yang harus mentransfer isi dokumen kurikulum melainkan sebagai pengembang kurikulum sekaligus fasilitator dalam berdialog dengan peserta didiknya. Hubungan dialogis kedua belah pihak akan menjadi sarana terbentuknya teachable and learnable moment untuk memroses dan menghasilkan gagasan-gagasan kreatif majinatif (Supriatna, 2019).

Dalam pendidikan saat ini, guruguru sejarah muda harus mampu merubah pola pikirnya untuk mengemas pembelajaran sejarah menjadi sangat menarik. Problem-problem pembelajaran dengan metode ceramah harus sedikit dikurangi. Apabila ceramah tetap digunakan harus didampingkan dengan metode-metode pembelajaran inovatif lain, atau bahkan dengan menggunakan gabungan media pembelajaran yang baik dan sesuai kebutuhan. Guru sejarah harus berubah agar pembelajaran sejarah yang dikatakan kurang menarik menjadi menarik dan banyak disukai.

Guru sejarah di era globalisasi saat ini dapat menawarkan pembelajaran yang sesuai dengan kebutuhan dan perkembangan zaman. Guru sejarah dapat berkreativitas dengan memanfaatkan atau menciptakan sebuah media pembelajaran yang dibutuhkan peserta didik. Pembelajaran yang inovatif akan menambah kenyamanan dalam belajar. Pembelajaran sejarah sendiri, meskipun didalam kelas dengan menghadirkan media akan akan menjadi menarik dan meningkatkan wawasan peserta didik dalam memahami dan menganalisis setiap materi pelajaran sejarah.

\section{Guru Sejarah Memiliki Inovatif dan} Kreatif dalam Memanfaatkan Media Pembelajaran

Saat ini sesuai tuntutan perkembangan zaman, pengaruh-pengaruh untuk merubah warna dunia pendidikan terus bergulir. Guru sejarah yang biasanya berpegang pada buku teks sejarah harus berbenah. Saat ini buku teks sebagai rujukan belajar memang masih sangat vital, namun pemanfaatannya harus didesain lebih kreatif dan inovatif lagi agar mampu menimbulkan minat belajar sejarah. Di lapangan banyak siswa yang mengeluh bahwa pelajaran sejarah hanya menghafal dan membosankan. Permasalahan demikian yang menimbulkan guru sejarah harus 
berinovasi dengan media pembelajaran saat ini. saat ini guru-guru sejarah yang mudamuda banyak yang memiliki pemahaman dalam mendesain media pembelajaran yang sesuai kebutuhan sekolah. Terkadang pembelajaran sejarah berisi materi yang menarik yang dikemas dalam media yang bagus dan menimbulkan rasa penasaran peserta didik. Rasa penasaran yang terus timbul ini menimbulkan minat belajar sejarah yang tinggi. Sejarah yang biasa dianggap hanya menghafal harus segera dirubah pola pikirnya. Media pembelajaran yang inovatif hasil kreativitas guru-guru sejarah tentu menjadi solusi yang cocok untuk diterapkan di era 4.0 saat ini.

Menurut Hosnan dalam (Sadikin, 2019), pembelajaran yang harus diimplementasikan guru didalam kelas harus mempunyai beberapa karakteristik yakni; (1) Pembelajaran berpusat pada peserta didik; (2) menegembangkan kreativitas peserta didik; (3) menciptakan suasana yang menarik, menyenangan, dan bermakna; (4) mengembangkan berbagai kemampuan yang bermuatan nilai dan makna; (5) belajar melalui berbuat yakni peserta didik aktif berbuat; (6) menekankan pada panggilan, penemuan dan penciptaan serta; (7) menciptakan pembelajaran situasi nyata dan konteks sebenarnya yakni melalui pendekatan kontekstual.

Pengajar Sejarah memiliki peranan yang sangat penting dalam keseluruhan proses pembelajaran sejarah. Selain mengembangkan bentuk-bentuk alat bantu pembelajaran yang secara mekanis dan mengembangkan pendidikan yang terfokus pada kemajuan peserta didik, guru sejarah juga memegang peranan penting dalam membuat pelajaran sejarah menjadi lebih hidup dan menarik bagi peserta didik yang diajarkannya. Salah satu hal terpenting adalah menjadikan manusia yang memiliki rasa tanggung jawab yang tinggi, bekerja keras, rela berkorban, dan tidak melupakan kearifan lokal bangsanya (Susilo, Agus \& Wulansari, 2019).

Sikap inovatif merupakan salah satu dari karakteristik siswa yang bisa melahirkan sesuatu yang baru, baik berupa gagasan maupun karya nyata, yang realatif berbeda dengan apa yang sebelumnya telah ada. Sikap inovatif siswa juga merupakan informasi yang penting bagi guru untuk memberikan pembelajaran, karena dengan mengetahui sikap inovatif dari siswa inilah guru dapat menentukan strategi pembelajaran yang tepat. Pada mata pelajaran sejarah sikap inovatif siswa sangat penting untuk mencapai keberhasilan pembelajaran siswa untuk mengukur sejauh mana dapat menampung pembelajaran dan mengaktualisasikan dengan mempraktekkan dan menghasilkan satu karya yang diharapkannya pada tujuan pembelajaran (Abrianto, Danny dan Sitompul, 2014).

Media pembelajaran banyak macam-macamnya yang selih berganti 
bermunculan. Guru sejarah yang kurang memiliki waktu untuk membuat media pembelajaran dapat memanfaatkan media pembelajaran yang telah ada. Beberapa tawaran penggunaan media pembelajaran semakin membuat pekerjaan guru-guru lebih ringan. Guru sejarah dapat menggunakan berbagai media yang menurutnya sesuai dengan kebutuhan peserta didiknya. Apa lagi saat ini penerapan kurikulum 2013, penerapan media pembelajaran inovatif harus digunakan agar tetap memiliki kemajuan yang luar biasa.

Pencapaian tujuan pembelajaran tidak lepas dari peran pendidik dalam mendidik peserta didik agar menjadi manusia yang selalu mengikuti perkembangan zaman tanpa meninggalkan akar budaya. Pendidikan yang di sisipkan budaya dan karakter dapat membentuk nilai dan karakter sebagai anggota masyarakat, dan warga negara yang religious, nasionalis, produktif dan kreatif. Oleh karena itu, pendidik dituntut menjadi pendidik yang bisa menjembatani kepentingan dan memfasilitasi kebutuhan pendidikan tersebut melalui usaha nyata yang bisa diterapkan dalam mendidik peserta didiknya. Salah satu usaha nyata yang diterapkan pendidik dalam proses pembelajaran adalah dengan memanfaatkan media dalam proses pembelajaran Penggunaan media pembelajaran dalam pendidikan dapat memberikan stimulus terhadapap minat belajar peserta didik dapat meningkat (Mansur, 2020).

$$
\text { Pemanfaatan teknologi dalam }
$$

proses pembelajaran mendorong terciptanya beragam media pembelajaran yang bisa dipilih untuk digunakan dalam pembelajaran. Penggunaan media elektronik seperti komputer, laptop, dan smartphone merupakan alternatif pemilihan media pembelajaran di abad ini. teknologi saat ini merupakan langkah solusi dalam yang dapat menimbulkan gaya belajar siswa. Kemajuan teknologi di dunia pendidikan dengan dukungan jaringan komunikasi yang baik akan menambah wawasan dan prestasi siswa jika dikembangkan dengan baik (Hertiavi, 2020).

\section{Guru Sejarah Berinovasi dengan Media}

\section{Pembelajaran}

Strategi yang digunakan untuk mengatasi permasalahan yang ada disini yaitu strategi pembelajaran dengan prinsip konstruktivisme, dimana guru berperan sebagai pembimbing dalam proses pembelajaran sedangkan siswa akan secara aktif sendiri untuk membangun dan mengembangkan pengetahuan serta pemahaman mereka. Inovasi pembelajaran yang dilakukan disini adalah dengan memberikan suatu inovasi pembelajaran kelompok, dimana siswa akan membentuk kelompokkelompok kecil. Setelah itu kelompok-kelompok tersebut diberi materi yang kemudian dijadikan sebagai bahan 
diskusi kelompok-kelompok tersebut, setelah mereka melakukan diskusi mereka harus mempresentasikan hasil diskusinya.

Dalam sesi presentasi siswa lain yang berasal dari luar kelompok tersebut diperbolehkan untuk menanggapi apa yang dipresentasikan oleh kelompok tersebut, entah itu dalam bentuk pertanyaan atau tambahan. Dari pembelajaran ini maka siswa dipacu untuk sama-sama berfikir, sehingga dari sini secara tidak langsung pengetahuan dan pemikiran siswa akan berkembang dengan sendirinya karena siswa sering aktif dalam berfikir (Pramayogi, 2019).

Menurut Daryanto \& Rahardjo dalam (Susilo \& Irwansyah, 2019), Mutu pendidikan dengan sendirinya akan tercermin dari mutu sumber daya manusia, dimana sumber daya manusia kita pada umumnya masih rendah, berarti mutu pendidikan saat ini mayoritas masih rendah. Pemahaman tentang perilaku siswa dalam proses belajar merupakan yang sangat penting terutama bagi guru. Ada kecenderungan saat ini untuk kembali pada pemikiran bahwa anak akan lebih baik jika lingkungan diciptakan alamiah. Belajar akan lebih bermakna jika anak mengalami apa yang dipelajarinya, bukan mengetahuinya.

Pembelajaran berorientasi pada penguasaan materi yang bertujuan memotivasi siswa untuk memahami makna materi pelajaran yang dipelajarinya dengan mengaitkan materi tersebut dengan konnteks kehidupan mereka sehari-hari (konteks pribadi, sosial, dan kultural) sehingga siswa memiliki pengetahuan/keterampilan yang secara fleksibel dapat diterapkan (ditransfer) dari satu permasalahan/konteks. Maka hasil dari suatu kerja keras dunia pendidikan nantinya akan dihasilkan luaran peserta didik yang telah siap memasuki era globalisasi yang modern seperti saat ini.

Dampak penggunaan media inovatif dalam bagi dunia pendidikan di sekolah akan meningkatnya kemampuan guru dalam merancang dan melaksanakan pembelajaran yang menerapkan media pembelajaran inovatif, meningkatnya kemampuan mengorganisasi materi dan mengelola pembelajaran dan dapat memanfaatkan waktu pembelajaran dengan baik, meningkatnya aktivitas belajar siswa yang cukup berarti pada aspek keterlibatan siswa dalam pembelajaran klasikal dan ketekunan siswa saat bekerja dalam kelompok. Siswa memperoleh pengalaman langsung dengan hadirnya media inovatif ditengah pembelajaran yang akan menjadikan siswa lebih memahami materi sejarah. Pembelajaranpembelajaran inovatif yang diajarkan juga nantinya akan membawa siswa 
mengalami proses belajarnya yang dilakukan dengan caranya sendiri akan membekas dalam waktu yang lama (Andrijati, 2014).

\section{Tantangan dalam Memanfaatkan}

\section{Media Teknologi}

Dalam era globalisasi saat ini dengan tuntutan zaman yang serba teknologi, menjadi tantangan tersendiri bagi para guru sejarah dalam memanfaatkan teknologi untuk menunjang pembelajaran yang selama ini dilakukan. Adanya kemampuan guru sejarah dalam menyusun materi ajar yang didesain secara inovatif, variatif, menarik, kontekstual, dan sesuai dengan tingkat kebutuhan peserta didik tentunya akan menjadi pembeda dipembelajaran sebelumnya dengan zaman sekarang. Belajar didalam kelas dengan memanfaatkan sumber belajar yang telah didesain juga akan menarik. Guru sejarah dapat menghadirkan materi yang ada dilapangan dengan didesain menjadi video pembelajaran untuk digunakan didalam kelas. Tentunya hal tersebut sangat menarik untuk dikembangkan oleh guru sejara agar pembelajaran menjadi tidak membosankan dan menjenuhkan (Ilmiawan, 2018).
Di abad ke-21 dimana semua yang terjadi dunia ini terpengaruh oleh globalisasi yang juga menghampiri dunia pendidikan seharusnya guru juga terus berjuang untuk tetap komitmen mendidik anak didiknya dan mengajarkan nilai karakter bangsa. Inovasi pembelajaran sangat diperlukan dalam dunia pendidikan, maka dari itu munculnya globalisasi harus dimanfaatkan dampak positifnya dan menghindari dampak buruknya bagi pendidikan. Memberikan motivasi kepada siswa, di era globalisasi saat itu semangat belajar siswa harus bertambah tinggi dan lebih baik sehingga memperoleh prestasi belajar yang lebih tinggi. Abad-21 globalisasi boleh muncul dan berkembang, namun prestasi dan nilai karakter bangsa tetap terjaga dengan baik. Dalam pembelajaran Sejarah, seorang guru perlu menerapkan inovasi pembelajaran yang dirancang untuk membantu siswa agar mudah memahami fakta, peristiwa, konsep, dan generalisasi melalui pengalaman belajar empiris. Pembelajaran Sejarah perlu menggunakan berbagai media yang mempunyai potensi untuk menambah wawasan dan konteks belajar serta meningkatkan hasil belajar Sejarah (Susilo \& Sarkowi, 2018)

Menurut Rusby dalam (Tafonao, Talizaro \& Ristiono, 2020), Setiap media pembelajaran yang dikembangkan oleh guru sejarah memiliki tantangan dan keunggulan 
masing-masing, maka sudah selayaknya guru sejarah dapat memilih media yang sesuai dengan kebutuhan atau tujuan pembelajaran yang ingin dicapai oleh guru sejarah. Penggunaan media yang dikembangkan tersebut memang memiliki tujuan untuk meningkatkan mutu pembelajaran. Tantangan dalam pengembangan media tersebut, maka guru sejarah dituntut untuk mengembangkan keterampilan dalam mendesain media yang akan digunakan dalam setia pembelajaran di sekolah. Untuk menghadapi tantangan tersebut, pemilihan media harus secara benar dan kongkrit untuk mengurangi aspek verbalisme.

Tujuan dari pembelajaran berbasis media masa yakni menjadikan peserta didik memiliki pemahaman tentang metodologi dalam sejarah. Karena pada dasarnya proses interpretasi dalam sejarah dapat dilakukan buka hanya oleh sejarawan dan kalangan peneliti lainnya, melainkan interpretasi juga dapat dilakukan oleh peserta didik dalam rangka menciptakan keseimbangan dalam pembelajaran sejarah. Pada saat peserta didik menghayati, menerima, membaca atau mendengar atas suatu peristiwa baik yang disampaikan melalui teks, televisi maupun penuturan, maka ia mempertemukan dunia yang dianjurkan oleh stimulus yang ada dengan dunianya yang kongkrit. Jika peserta didik memiliki bekal pengetahuan tentang metodologi sejarah, akan muncul suatu toleransi akademis dalam pemikirannya yang pada akhirnya menjadikan setiap perbedaan tersebut membuat dirinya semakin bijak dan arif (Nugroho, 2019).

Dalam Kurikulum 2013 yang merupakan kurikulum terbaru yang diterapkan dalam pendidikan di Indonesia mempunyai prinsip,yaitu: pertama, pembelajaran berpusat pada peserta didik dan memberikan kesempatan untuk mengasimilasi dan mengakomodasi konsep. Kedua, memberikan kesempatan untuk melatih kemampuan dalam komunikasi dan merekonstruksi pemikirannya sendiri (Krismawati, 2018).

Perlu kita tahu bahwa saat ini sangat berbeda dengan zaman dahulu. Pelajaran sejarah zaman dahulu banyak bercerita tentang masa lampau dan diakui sebagai belajar menghafal. Saat ini, guru sejarah muda harus lebih mau membuka diri terhadap kemajuan dari munculnya globalisasi. Sangat perlu dipahami bahwa teknologi yang berkembang saat ini memiliki peran yang sangat cepat. 
Teknologi bagi guru sejarah dapat digunakan untuk menghubungkan antara guru dan peserta didik dalam kondisi apapun. Pembelajaran sejarah yang biasa ditayangkan didalam kelas, pada masamasa tertentu dapat dilakukan di luar ruangan, atau bahkan dengan pembelajaran online. Dunia pendidikan bukan hanya sebatas belajar dalam lingkup kelas, namun dapat dilakukan dimanapun jangkauannya. Justru akan sangat menarik jika sebuah materi pembelajaran digunakan dengan bantuan media pembelajaran.

Penggunaan media pembelajaran yang inovatif saat ini juga mengharuskan pihak sekolah memberikan fasilitas yang baik dalam mendukung kiprah guru dalam menggunakan media inovatif. Apabila dukungan fasilitas pembelajaran yang baik, akan mempermudah realisasi pembelajaran lewat media. Guru-guru sejarah akan banyak menyerap pengalaman-pengalaman berharga yang nantinya dapat diterapkan kepada peserta didiknya. Bagi peserta didik, tentunya media pembelajaran yang inovatif juga sangat baik dalam mendukung proses belajar mengajarnya. Banyak ilmu dan pengetahuan baru yang diserap. Meskipun demikian, penerapan media pembelajaran harus berdasarkan pendidikan karakter peserta didik. Jangan sampai media melupakan karakter siswa. Peserta didik dengan adanya media harus tetap diarahkan dalam penerapan media berdasarkan karakter sendiri.
Menurut (Akbar, Amin \& Noviani, 2019), dalam mengatasi hambatan dan tantangan dalam pemanfaatan media pendidikan di Sekolah harus dipenuhi beberapa hal sebagai berikut. Pertama, guru dan siswa harus memiliki akses terhadap teknologi digital dan internet dalam kelas, sekolah, dan lembaga pendidikan. Ini berarti sekolah harus memiliki sarana prasarana yang memadai yang berkaitan dengan teknologi informasi dan komunikasi. Kedua, harus tersedia materi yang berkualitas, bermakna, dan dukungan kultural bagi guru dan siswa. Materimateri ini dapat berupa materi pembelajaran interaktif yang berbantuan computer/laptop, seperti CD, DVD dan infocus dalam pembelajaran interaktif. Ketiga, guru harus memiliki pengetahuan dan keterampilan dalam menggunakan alat-alat dan sumbersumber digital dalam kegiatan belajar mengajar agar tercapai Standar Kriteria Ketuntasan Minimal (KKM). Keempat, harus tersedianya anggaran atau dana yang cukup untuk untuk mengadakan, mengembangkan dan merawat sarana prasarana Teknologi Informasi dan Komunikasi tersebut. Kelima, harus adanya kemauan dan dukungan dari semua pihak, dalam hal ini kepala 
sekolah, guru, dan peserta didik untuk menerapkan pembelajaran dengan dukungan teknologi komunikasi dan informasi tersebut.

\section{SIMPULAN}

Problem dalam dunia pendidikan saat ini adalah bagaimana peran guru dalam menghasilkan siswa-siswa yang berprestasi dan memiliki aspek yang baik. Problemproblem seputar pendidikan juga berimbas pada guru-guru sejarah yang banyak dinilai hanya berpedoman pada buku pegangan saja dan pelajaran sejarah dianggap membosankan. Era globalisasi saat ini, sudah selayaknya guru-guru sejarah muda menjadi agen perubahan bagi dunia pendidikan saat ini. pelajaran sejarah yang sebelumnya dianggap membosankan bagi siswa harus dimodifikasi menjadi pelajaran yang penting bagi siswa.

Problem tersebut dapat terwujud dengan kehadiran guru-guru sejarah yang memiliki kreativitas dan mau berinovasi terhadap teknologi dalam pembelajaran sejarah. Pelajaran sejarah yang banyak menghadirkan kisah-kisah di masa lalu atau berkaitan dengan peninggalan-peninggalan yang bernilai sejarah tinggi, dapat dijadikan bahan pelajaran dengan sentuhan media inovatif yang dikembangkan oleh guru-guru sejarah. Kreativitas dan inovatif guru sejarah dalam berkarya tentunya akan menambah wawasan dan ilmu pengetahuan bagi siswa. Pengalaman yang membekas bagi siswa sangat berharga dari pada sebuah hafalan semata. Sejarah akan dipandang penting dan menjadi pelajaran yang sangat dirindukan oleh siswa di masa kinii dan masa yang akan datang.

\section{DAFTAR REFERENSI}

Abrianto, Danny dan Sitompul, H. (2014). Penggunaan Media Pembelajaran Berbasis Komputer dan Sikap Inovatif Terhadap Hasil Belajar Teknologi Informasi dan Komunikasi. Jurnal Teknologi Informasi \& Komunikasi Dalam Pendidikan, 1(1), 50-62.

Agustiningsih, Nur \& Fitri, N. (2019). Pengembangan Media Pembelajaran Berbasis Blended Learning Program Studi Pendidikan Sejarah Universitas Batanghari Jambi. Diakronika, 19(2), 127-140.

Akbar, Amin \& Noviani, N. (2019). Tantangan dan Solusi Dalam Perkembangan Teknologi Pendidikan di Indonesia. PROSIDING SEMINAR NASIONAL PENDIDIKAN PROGRAM PASCASARJANA UNIVERSITAS PGRI PALEMBANG 03 MEI 2019, 18-25.

Andrijati, N. (2014). Penerapan Media Pembelajaran Inovatif Dalam Pembelajaran Matematika Sekolah Dasar Di Pgsd Upp Tegal. Jurnal Penelitian Pendidikan Unnes, 31(2), 125160. https://doi.org/10.15294/jpp.v31i2.5696

Arikunto, S. (2013). Prosedur Penelitian Suatu Pendekatan Praktik. Jakarta: Rineka Cipta.

Asmi, A. R. (2019). Pengembangan Media Pembelajaran Audio berbasis Podcast pada Materi Sejarah Lokal di Sumatera Selatan. Historia: Jurnal Pendidik Dan Peneliti Sejarah, 3(1), 49-56. https://doi.org/10.17509/historia.v3i1.210 17

Hasan, S. H. (2019). Said Hamid Hasan Pendidikan Sejarah untuk Kehidupan Abad Ke 21 M. HISTORIA: Jurnal Pendidik Dan Peneliti Sejarah, II(2), 6172.

Hertiavi, M. A. (2020). Penerapan E-Learning dengan Platform Edmodo untuk Meningkatkan Hasil Belajar Mahasiswa. Jurnal Komunikasi Pendidikan, 4(1), 1-8.

Ilmiawan, A. (2018). Pengembangan Buku Ajar 
Sejarah Berbasis Situs Sejarah Bima (Studi Kasus pada Siswa Kelas X MAN 2 Kota Bima). JISIP, 2(3), 102-106.

Istiarsono, Z. (2016). Tantangan Pendidikan Dalam Era Globalisasi: Kajian Teoretik. Jurnal Intelegensia, 1(2), 19-24.

Joebagio, H. (2017). Tantangan Pembelajaran Sejarah di Era Globalisasi. ISTORIA: Jurnal Pendidikan Dan Ilmu Sejarah, 13(1), 55-62. https://doi.org/10.21831/istoria.v13i1.176 17

Krismawati, N. U. (2018). Kebutuhan Bahan Ajar Sejarah di SMA. Cendikia, 16(2), 355-374.

Kristanti, I., \& Umamah, N. (2019). Jurnal Historica THE CHARACTER-BASED MODULES AND THEIR INFLUENCE ONHISTORICAL AWARENESS OF STUDENTS OF CLASS XI MIPA 4 SMAN PASIRIAN. Historica, 3(2252), 78-89.

Mansur, H. \& R. (2020). Pengembangan Media Pembelajaran Infografis untuk Meningkatkan Minat Belajar Mahasiswa. Jurnal Komunikasi Pendidikan, 4(1), 3748.

Minsih \& Galih D, A. (2018). Peran Guru dalam Pengelolaan Kelas. PROFESI PENDIDIKAN DASAR, 5(1), 20-27.

Nugroho, F. (2019). Penggunaan Sumber Belajar Dalam Pembelajaran Sejarah Kontroversial. NOSARARA : JURNAL PENDIDIKAN DAN ILMU SOSIAL, 7(2), 177-191.

Pramayogi, D. (2019). Inovasi dalam pembelajaran sejarah. SINDANG: Jurnal Pendidikan Sejarah Dan Kajian Sejarah, 1(2), 17-22.

Ratumanan, T. . (2015). Inovasi Pembelajaran. Yogyakarta: Ombak.

Risma, Juraid, dan S. (2016). PENGEMBANGAN MEDIA PEMBELAJARAN SEJARAH MELALUI PEMANFAATAN WEBSITE PADA KELAS XII TKJ 2 SMK NEGERI 1 BANAWA KABUPATEN DONGGALA. E Jurnal Katalogis, 4(10), 1-9.

Sadikin, M. (2019). Pemanfaatan Media Gambar Mata Pelajaran Sejarah Di Kelas $X$ Ips Sma Muhammadiyah 2 Pontianak. 19(2), 121-126.

Setiono, Panut \& Rami, I. (2017). Kreativitas Guru Dalam Menggunakan Media Pembelajaran Di Kelas V Sekolah Dasar.
JURNAL GENTALA PENDIDIKAN DASAR, 2(2), 219-236.

Sugiyono. (2018). Metode Penelitian Pendidikan Pendekatan Kuantitatif, Kualitatif, dan $R \& D$. Bandung: Alfabeta. Supriadi, D. (2017). Implementasi Manajemen Inovasi dan Kreatifitas Guru dalam Meningkatkan Mutu Pembelajaran. Indonesian Journal of Education Management and Administration Review, 1(2), 125-132.

Supriatna, N. (2019). Pengembangan Kreativitas Imajinatif Abad Ke-21 Dalam Pembelajaran Sejarah. HISTORIA: Jurnal Pendidik Dan Peneliti Sejarah, II(2), 7382.

Susilo, Agus \& Wulansari, R. (2019). Kuliah Lapangan Sejarah Sebagai Penguatan Pendidikan Karakter Mahasiswa STKIP PGRI Lubuklinggau. Criksetra: Jurnal Pendidikan Sejarah, 8(2), 1-17.

Susilo, A., \& Irwansyah, Y. (2019). Pendidikan Dan Kearifan Lokal Era Perspektif Global. SINDANG: Jurnal Pendidikan Sejarah Dan Kajian Sejarah, 1(1), 1-11. https://doi.org/10.31540/sdg.v1i1.193

Susilo, A., \& Sarkowi, S. (2018). Peran Guru Sejarah Abad 21 dalam Menghadapi Tantangan Arus Globalisasi. Historia: Jurnal Pendidik Dan Peneliti Sejarah, 2(1),

43. https://doi.org/10.17509/historia.v2i1.112 06

Tafonao, Talizaro \& Ristiono, Y. B. (2020). Peran Guru Agama dalam Meningkatkan Mutu Pembelajaran dengan Bantuan Multimedia. Jurnal Komunikasi Pendidikan, 4(1), 9-17.

Tafonao, T. (2018). Peran Media Pembelajaran Dalam Meningkatkan Minat Belajar Mahasiswa. Jurnal Komunikasi Pendidikan, 2(2), 103-114. 